\title{
The importance of human capital and the human organization management in a crisis situation
}

\author{
Alexandru - Sebastian LAZAROV \\ University POLITEHNICA of Bucharest, Bucharest, Romania \\ Alexandru.lazarov@yahoo.com
}

\begin{abstract}
The main attributes of an organizations are characterized as open and dynamic social systems, able to develop individually. In essence, an organization is a social system with human capacity, beyond the means of production, essential to the formation, operation and development of an organization. Interactions between people and the connections between them are important in achieving the goal of the organization. The objectives of the organization must coincide with the goals of the organization's leadership and meet the needs of those involved in the production system, so the level of connection between human capital and resources is essential. Human capital is the most important factor for the organization, it represents the accumulation of professional skills, combined with the creativity and initiative of each person, together generating essential resources to the organization and producing services and materials meant to generate profit. Each organization invests in forming and developing the human capital in order to create specialists in the industrial branches that the organization develops. Satisfaction with the basic needs of employees is an essential factor in the organization's development. If this is not the case, the human capital can be destabilized slightly and can cause the state of crisis. Defeating human primordial needs can lead to an increase in the state of crisis of the organization, thus being able to evolve until the collapse of the organization.

Human capital, in the event of a crisis, regardless of its nature, is the most important factor. The human factor decides how the crisis will be perceived and the means used to end the crisis.Knowing the human capital, the needs and especially the abilities of each employee can help the organization overcome a crisis moment easily and can solve an emergency without involving all the factors at its disposal.
\end{abstract}

Keywords: human capital, human factor, human organization management, state of crisis, organization needs, level of connection.

\section{Introduction}

Industrial organizations contribute to the development of modern society and the speed with which industries and technologies are developing.

The organizational structure decisively influences the nature of human interaction and the perception of the organization. The size of the organization, the number of hierarchical levels the number of departments, the functional substructures, the complexity of the activity place their mark on the whole organizational activity, determining the content and significance of the messages resulting from the behaviour of the organization. The structure of the organization gives us an insight into the basic features of the organization: human resources, the number of members of the organization, financial resources and material resources.

The structure reflects the organizational hierarchy, which targets the power relations within the organization and allows the knowledge of the internal communication processes, the communication structures and the distance between these structures and the decision centers.

The human capital of the organization is defining its identity and image. Essential to the organization are, at the same time, the relationships of people and the relationships of each man with the overall structure of the organization. The quality of the people determines the quality of the organization and, therefore, a major concern is required to achieve the socialization and professionalisation of each individual. An important role is playing in this perspective the organizational intellectual capital (Bratianu, 2011, 2013). 
The way management is done at the organization level is directly proportional to its ability to absorb information and implement it in order to increase the production rate or maintain the organization at an optimum level of production. At the same time, efficient management foresees and avoids the organization's entry into poor situations, crisis situations. If management is at the organization level, it goes through different crisis situations caused by internal / external factors or by a combination of factors even independent of its production capacity. Thus, we focus on the situation of crisis management at the level of the industrial organizations, how they impose an imprint on an organization such a situation and at the same time the methods and means by which an organization can avoid and overcome a period of crisis.

Depending on the nature of the causes of the crisis, the way of prevention and reaction of the organization, it may be more affected or less affected by the effects of the crisis.

Starting from the definitions and classifications of the types of crisis, their impact and their consequences must materialize the benchmarks for the implementation of a crisismanagement strategy at the level of the industrial organizations.

\section{Literature review}

We need to take into account several things that we need to discuss before a crisis occurs. To begin with, we need to develop a system to detect signals or to alert the emergence of a crisis quickly in order to identify the problems that may arise in a future crisis. Coombs (2012) recommends that we focus on threats or vulnerabilities that are most likely to occur and which have the most detrimental impact. According to Weiner (2006), research shows that the vast majority of crises occur when companies fail to identify a potential problem earlier and develop an action plan to manage the problem before it.

Pauchant and Mitroff (1992) say that a key step ahead of the crisis is to get the support of the senior management department to integrate crisis management into the organization's emergency planning. The prioritization of crisis planning and the integration of the crisis management process into organizational policies should be supported by senior management. According to Mandu (2007), the crisis management can be understood as a process that is followed by the managers and the management team for counteracting the action of the factors generating the crisis in order to prevent, limit or eliminate their effects and ensure the normal functioning of the organization. Also, crisis management can mean a system of knowledge and methodologies that offers those who lead elements regarding how they should lead in exceptional (crisis) situations. With or without the existence of a crisis plan, the reaction to the production of potentially dangerous situations is not lacking in the attention of the managers, but the efficiency can be maximum when the ideas are written and resulted from the creative exercises on scenarios of special situations. A list of measures to eliminate, limit, counteract the causes that generate the crises is needed. It is worth the trouble especially in the first moments of the crisis when the affective side of the managerial process dominates the rational one under the action of stress factors. This plan protects the manager who is in danger of making bad, unfounded, hasty decisions. Even if they are not convinced of the need for the plan, managers can turn to experts because the Learner from the disastrous experiences of others always proves useful. Dodd (2006) states that the person responsible for preparing for crisis situations must be one with direct responsibility and maximum accountability. Thus time and money resources must be managed in such a way as to maintain preparedness for crisis situations.

Lee, Woeste and Heath (2007) say that it is necessary to create and maintain a written crisis management plan to serve as the organization's response to a crisis and to train and train a team prepared to describe and detail this response as many times as needed. Even when organizations have a crisis management plan and a team to identify the crisis, they tend to fail 
in crisis planning. Training a team to lead the crisis has involved a review of the crisis management plan. People training and the formation of crisis management teams should go beyond other planning activities, the problem is that less than half of the existing companies are using this method.

Seeger (2006) supports the involvement of traditional media as a strategic resource to help manage the crisis. A team of spokespersons should be identified and trained to deal with the details of crisis management in the environment of the organization. According to Duhe (2005), the organization has to use different spokespersons to increase credibility and reflect different kinds of expertise on a current crisis.

Developing the organization's online part by empowering content for and interacting with those interested. Kolek (2009) describes in his paper how Telsa Motors used the CEO's blog to explain the situation of employees and thus minimize chances for inaccurate media articles.

According to Fearn-Banks (2011), it is preferable to identify key messages that should be communicated to stakeholders. Boin (2009) claims that key messages should include statements of concern for the injured or killed and what the organization does to manage the crisis.

When necessary, self-evaluation messages should be considered. According to Heath (2006), the message can instruct people on what they can do to protect themselves, to help others, or to take action that might be significant in more abstract or social contexts.

According to Dodd (2006), the organization will want to return as soon as possible to the current situation, as it does before the occurrence.

\section{Methodology}

Between February and April 2016, the crisis of the Romanian baby sickness appeared. During this period 3 babies died, several children from Argeș county were admitted, which led to the emergence of many hypotheses regarding the causes of things that happened. The crisis was accentuated by the media, the state institutions being pressured to find out what were the causes that led to these diseases. In February, in Pitesti, samples were taken from a fresh cow's cheese from a store. At the end of the month, the Minister of Agriculture, Achim Irimescu, said that the E-coli bacteria was found in the cheese sample, the cheese being produced by the Brădet company.

\section{Brădet company and its human organization management during crisis situation}

The only strategy the company adopted during the crisis was the one it adopts in its daily life, transparency and honesty. Regarding the establishment of the communication strategy, the owner of the company said that at that time, he had to take the initiative and be open to the public, trying to be as transparent and sincere as possible to his public to give them confidence and to lessen the crisis situation already created.

At the beginning of March, after the scandal began in the media, the human capital dealing with crisis management posted the first message, with a defensive and modest tone. The second message posted on the company's Facebook page is a call to action of all Romanians. The crisis management team wanted to involve in the business all those who wanted that thing, so that every Romanian could buy shares.

On March 9, the first official version of the analyzes is communicated, from which it appears that the cheese produced by the Brădet company had nothing to do with the sickness of the babies.

The strategy adopted by the crisis management team, that of being honest and transparent in everything, was the basis of the communication on the company's Facebook page. The messages were sincere and did not bypass the topics exposed by the media and 
authorities, informing the clients of the company constantly and always coming back with messages according to their curiosity. The communication with the partners of the company was made constantly, the stores where the factory had sales being kept permanently updated with everything that happened. The community has shown solidarity with the company, the City Hall supporting the factory throughout the crisis.

\section{Brădet company and its human organization management after crisis situation}

Due to the strategy adopted by the crisis management team, the partner stores supported the company, following the crisis, their products being found in several stores and having a greater range of commercialized products. The platform created by the company, allowed the Romanians to become shareholders of the company, thus it registered a significant number of shareholders and for two months after its development it managed to raise the amount why it deposited 100,000 lei.

\section{Results and discussions}

Based on the above, I have created a table to highlight the strategies adopted by the human capital dealing with crisis management of Brădet's company:

Table 1 The results of the strategies adopted by the human capital dealing with crisis management of Brădet's company

\begin{tabular}{|c|c|c|c|}
\hline The company & $\begin{array}{l}\text { Time of reaction to the } \\
\text { crisis situation }\end{array}$ & The strategies adopted & Results \\
\hline Brădet & $\begin{array}{l}\text { Immediately after the } \\
\text { crisis }\end{array}$ & $\begin{array}{l}\text { - the company had a } \\
\text { positive attitude towards } \\
\text { the clients and } \\
\text { employees of the } \\
\text { company; } \\
\text { - the company } \\
\text { maintained a connection } \\
\text { with the public } \\
\text { throughout the crisis; } \\
\text { - all statements of the } \\
\text { company were honest } \\
\text { and transparent; } \\
\text { - the company's partners } \\
\text { have always been kept } \\
\text { up to date with } \\
\text { everything that happens; } \\
\text { - the platform created } \\
\text { that allowed the } \\
\text { Romanians to become } \\
\text { shareholders of the } \\
\text { company. }\end{array}$ & $\begin{array}{l}\text { - the company has } \\
\text { regained the confidence } \\
\text { of its consumers and has } \\
\text { attracted other } \\
\text { consumers of the } \\
\text { products; } \\
\text { - the products of the } \\
\text { company can be found in } \\
\text { several stores, having a } \\
\text { greater range of products } \\
\text { marketed; } \\
\text { - the platform created has } \\
\text { registered a significant } \\
\text { number of shareholders } \\
\text { and for two months since } \\
\text { its development it has } \\
\text { managed to raise over } \\
\text { 100,000 lei. }\end{array}$ \\
\hline
\end{tabular}

Source: Authors' own research

Brădet's strategy implemented by the strategy management team managed not only to avoid its collapse, but also to regain the trust of its consumers and to attract other consumers of the products. Through the strategy adopted by the team of people who dealt with the crisis management, the company had a positive attitude towards the customers and the employees of the company, being always honest and transparent through the statements it gave. Another beneficial thing was that all the partners of the company were always kept abreast of everything that happened, as proof that they and the City Hall supported the company when 
the statements given by the Minister of Agriculture appeared in the press, which meant a plus to combat the crisis period more easily.

\section{Organization management}

Organization management is a structured part of management, the most common one being based on the need for a market economy. It must provide and structure a well-defined plan for achieving the organization's goals and mitigating the risks the organization may face. Depending on the country where the organization is active, the number of employees, the scope of activity, climate and resources, the organization's management varies. First of all, the organization has to operate in close proximity to the resources it needs in the production process. Also, the management capacity of the organization also means how to use the resources they have, having a multidisciplinary character, by analysing sociologically the factors they have, the factors they need, the productivity degree the organization can raise, and especially vision made to design and anticipate crises.

Managing processes have to take into account the cumulative workmanship between the execution processes that comprise the workforce, the products and services used, and the role of the recruitment and human resources team, the qualities of the management team and its outlook. The management has to take into account the social-economic, technical-material components, but above all human, able to cope with the management process of the organization. The forecast is both anticipating production capacity and possible impediments in the production process. The management team has to take into account the predictive forecasting prognosis, choosing a temporary variable for which they will make a realistic forecast in which the organization's plans are shaped and developed. The plans should be mandatory for industrial organizations, representing a realistic objective assumed for a period ranging from one month to five years, include a number of programs through which these plans will materialize. The programs are detailed, including a high degree of certainty of production, designed to lead to the implementation of the plans. The programs include details of supplies, quantities, finished products, warehousing and sales.

All the steps detailed above can be accomplished by communicating, delivering the message in a clear, precise manner, a quality of management that can support the organization or make it harder for development.

\section{Crisis management plan}

The crisis management plan involves prioritizing action. The priority being staff and how they perceive and understand the crisis. The most important component of an organization is the human component. Thus, with the help of the communication, the staff must be properly informed and work with the management team when necessary to overcome the crisis. In order of priorities, the materials and equipment come in order to ensure normal production.

In the event of an IT crisis in an industrial organization, the whole process is blocked, thus checking the sources that caused the crisis, the documents and information that can be saved, the degree of network damage and the percentage of recoverable information. Generally, computer systems have a back-up process able to save most data, but there may be human mistakes and this process can not be done on time. The most dangerous computer losses can occur in oil industries. Faulting a system can cause significant fuel leakage, environmental damage, and consistent financial damage. To prevent such incidents, oil companies have a permanent way of checking these systems, but in the case of disasters they have acted promptly and neutralized as far as possible the negative effects.

In the case of a timber-producing industry, landslides in the area concerned, floods, forest fires or termites invasions disrupt the organization's good functioning. In this way, it announces its customers and suppliers on the problem they are facing, trying with the existing 
resources to honor the orders already taken over and looking for new raw material collection areas. Sometimes natural disasters bring different industries to the stage of impossibility of continuing production.

A team is formed to carry out a plan, which operates under the strict supervision of the management or the public relations director. The team of specialists on various issues structured a communication plan capable of dealing with all possible questions that will arise. It is essential that during the crisis the organization knows how to communicate and who assumes the role of communicator or spokesperson. The activity of the crisis cell is a group activity where the entire team assumes responsibility. Team members need to know how to work in a team under stress, they have to take responsibility and discuss decisions before submitting a final form.

The members of the crisis cells must simulate a crisis, in order to act in good conditions in the event of a crisis. At the same time, members of the crisis cell, together with the management of the organization, must designate a person in charge of communication, a spokesman, to convey the message clearly and precisely to the public involved. The communication channel is not a fixed one, it must include both audio, video and text messages. Transmitting is done through both media and fax, telephone, email, meetings, display, internal notes, service orders.

\section{Human organization management before crisis situation}

Develop a network of strategic partnerships before the crisis that provides expertise and support in crisis situations and assists in the dissemination of true messages.

The key moment for an organization to take proactive steps to develop a systematic stakeholder communication process before the crisis is emerging to enhance the relationship with stakeholders. Key messages should strengthen:

- accessibility, competence, openness, transparency and honesty,

- the desire to involve and listen to those concerned with the goal of achieving results on both sides,

- empathy, concern and compassion.

\section{Human organization management during crisis situation}

You should consider to build a team by involving the right people in the process of developing the crisis plan, as well as effective communication with them.

Causes and consequences must be analyzed and solutions must be found to stop or reduce the effects of the crisis. The persons responsible for managing these types of crises should be appointed, and a group will be formed, which will always keep up to date, both the management of the company and its public.

The person responsible for crisis management should take into account the importance and effects of crisis communication. Strategic communication involves a good communication plan, including messages sent by the spokesperson to manage the crisis and solve the problems caused by it, but in particular, to start rebuilding the organization.

The spokesperson should not be changed during the crisis, the existence of a welldefined person, who knows all aspects of the crisis is essential in the relationship with the media. At the same time, it must have a clear, precise, explicit language, in order to be able to transmit real and useful information.

A crisis plan should be implemented by a crisis-management team that has been hired, as mentioned before. We have to admit that a crisis has certain characteristics: time pressure, control problems, level of threat that is different in magnitude, and constraints on response options. A well-built crisis management plan, including both training and simulations, will help the organization to manage these features of a crisis. 
A mix of media communication with internal auditors and outside audiences should be developed. In some situations, face-to-face encounters may be appropriate, while in others, it may be more beneficial to rely on updates to the organization's web page, RSS feeds, e-mail, Twitter, etc. Increased attention needs to be paid to disseminating stakeholder information as current generations spend more time using email, SMS and social media than watching television news or reading magazines.

The crisis control center must have a space capable of supporting a number of

PICBE $\mid 912$ journalists and people interested in the problem, very well equipped to be able to transmit and retrieve information. At the same time, the crisis control center must have a record of media appearances, documents of interest about the organization, personnel data, statistics. Access to databases is essential in case of crises. Databases have the most important details about the industrial organization, and easy access to them is essential, however, the databases, no matter what the nature of the cause of the crisis, must be kept and used safely. In the case of a computer crisis, by entering the databases, the organization can suffer a lot. The crisis, by its nature, affects information and production capacity. When the organization is affected by the crisis, the most important thing is to handle the information, both internal and external.

In order to facilitate the access to information, in times of crisis, the organization must make a fast, efficient, correct information, both to the employees, collaborators, clients and to those interested: the press and the local communities.

Strategic communication involves a good management and definition of the risks that the industrial organization faces, to manage the communication plan, including the messages transmitted by the spokesperson, to manage the crisis and to solve the problems caused by it, but especially to restore the organization.

\section{Human organization management after crisis situation}

The actions that need to be taken after the crisis has been resolved are to continue communicating with internal and external stakeholders (including the media), assessing the effectiveness and efficiency of the response to the crisis, updating the crisis management plan and perhaps the team crisis on the basis of evaluation and also to draw up a report that includes what the organization has learned in organizational processes and policies.

Most importantly, after the end of the crisis, it is the responsibility of the leaders of the organization to discuss strengths and weaknesses, set up a way of working and improve parts that did not work in parameters at the time of the crisis. Making a detailed report it is an essential and extremely useful tool in preventing and managing possible crises. Crisis management involves problem management, a report of risk factors, and the formation and maintenance of relationships with the public and private media, the media and mass media. A positive, solid image, an open and sincere communication through exchange of information and opinions can help avoid a crisis or the collapse of the organization.

The outcome of a crisis always depends on the degree of preparation of the members of the organization and their loyalty to the purpose and mission of the organization.

\section{Conclusion}

Crisis management creates, depending on its capacity, opportunities for the organization or succeeds in maintaining the organization's intact image. A good crisis management strategy is essential in the organization's operation and development.

Crisis management specialists must have communication skills, human psychology skills, but above all, the ability to empathize with people in the organization and the environment. For the efficiency of crisis management, the team has to work together well and communicate effectively. 
The dynamics with which the team manages the crisis situation characterizes the management process. We must keep in mind that any organization operates in a changing social environment, so any organization must act and react to profit, to adapt to market requirements.

Managers, have to be able to clearly determine what the organization's goals are, have to plan the actions to solve the organization's problems, empower employees and prepare them for possible changes. All managers have to evaluate employee performance and productivity.

The role of managers is essential in any situation, but at a time of crisis, they are most prepared to cope with the situation faced by the organization.

The objectives of the organization as an entity must coincide with the goals of the organization's leadership and meet the needs of those involved in the production system. Thus, the level of connection between human capital and resources is essential.

Human capital is the most important factor for the organization, it represents the accumulation of skills and professional skills, combined with the creativity and initiative of each person, together generating essential resources to the organization and producing services and materials meant to generate profits.

Human capital, in the event of a crisis, regardless of its nature, is the most important factor. The human factor decides how the crisis will be perceived and the means used to mitigate or end the crisis.

Knowing the human capital, the needs and especially the abilities of each employee can help the organization overcome a crisis moment easily and can solve an emergency without involving all the factors at its disposal.

In conclusion, the structure of each organizations are the identity element with direct consequences on all its components that gives distinction and specific image to the organization.

\section{References}

Boin, A. (2009) Introduction to the special issue, e new world of crises and crisis management: Implications for policymaking and research, Review of Policy Research.

Bratianu, C. (2011). A new perspective of the intellectual capital dynamics in organizations. In Vallejo-Alonso, B., Rodriques-Castellanos, A., \& Arregui-Ayastuy, G. (Eds.). Identifying, measuring, and valuing knowledge-based intangible assets: new perspectives, pp. 1-21. Hershey, NY: IGI Global.

Bratianu, C. (2013). Nonlinear integrators of the organizational intellectual capital. In Fathi, M. (Ed.). Integrative of practice-oriented knowledge technology: trends and perspectives, pp. 3-17. Heidelberg: Springer.

Coombs, W. T. (2012). Ongoing Crisis Communication: Planning, Managing, and Responding, 3rd edition, Thousand Oaks: SAGE Publications.

Dodd, D.W. (2006) Have we learned the lessons of disaster preparedness, College Planning \& Management.

Duhe, S. F. (2005) The sources behind the rst days of the anthrax attacks: What can practitioners learn?, Public Relations Quarterly, Spring 2005.

Fearn-Banks, K. (2011), Crisis Communications - A Casebook Approach, New York, Routledge.

Heath, R.L. (2006) Best practice in crisis communication: Evolution of practice through research, Journal of Applied Communication Research, August 2006.

Kolek, J. (2009) Managing a crisis and becoming a stronger organization, The Public

Lee, J., Woeste, J.H., \& Heath, R.L. (2007) Getting ready for crises: Strategic excellence, 
Public Relations Review.

Mandu, P. (2007), Course: Crisis management, University "Transilvania" of Brașov

Pauchant, T. C., Mitroff, I. I. (1992). Transforming the Crisis-Prone Organization, San Francisco: Jossey-Bass Publishers.

Seeger, M.W. (2006) Best practices in crisis communication: An expert panel process,

Journal of Applied Communication Research.

Weiner, D. (2006) Crisis communication: Managing corporate reputation in the court of public opinion, Ivey Business Journal. 